\title{
Paleomagnetism, rock-magnetism and geochemical aspects of early Cretaceous basalts of the Paraná Magmatic Province, Misiones, Argentina
}

\author{
Mabel Mena ${ }^{1,2}$, María Julia Orgeira ${ }^{1,2}$, and Silvia Lagorio ${ }^{2}$ \\ ${ }^{1}$ CONICET- INGEODAV, Argentina \\ ${ }^{2}$ Dto. Ciencias Geológicas, Facultad de Ciencias Exactas y Naturales, Universidad de Buenos Aires, Argentina
}

(Received December 20, 2005; Revised May 25, 2006; Accepted June 1, 2006; Online published November 8, 2006)

\begin{abstract}
The basalts of the Posadas Formation were extruded during the huge continental volcanism that affected the Paraná Basin in the Lower Cretaceous. We have carried out a paleomagnetic and rock-magnetic study on samples collected along a basalt outcrop section in Misiones, Argentina and determined that rocks classified as tholeiitic basalts and andesi-basalts are characterized by a low to intermediate content of Ti. Paleomagnetic and rockmagnetic studies suggest that the main magnetic mineral is low-Ti titanomagnetite of superparamagnetic (SP) to single-domain (SD) sizes, and very low amounts of multi-domain (MD) particles. The stable magnetic remanence enabled us to define characteristic remanent magnetizations (ChRMs) with a maximum angular deviation (MAD) $<5^{\circ}$ in most cases; and in all the cases, a MAD $<10^{\circ}$. The sequence has registered at least two polarity reversions, starting from a normal polarity at the base. The calculated virtual geomagnetic poles (VGPs) present an elongated distribution similar to other distributions of VGPs published for the Paraná Magmatic Province. The elongated distribution of the VGPs could be a real feature of the geomagnetic field at a time of frequent changes of polarity. Key words: Paleomagnetism, rock-magnetism, basalts, Paranv Magmatic Province, Cretaceous.
\end{abstract}

\section{Introduction}

The basalts of the Posadas Formation (Gentili and Rimoldi, 1980) that outcrop in north-eastern Argentina and extend into South Brazil, Paraguay and Uruguay where they are called the Serra Geral, Alto Paraná and Arapey Formation, respectively, belong to one of the largest continental volcanic provinces in the world. These lava flows are the product of the huge volcanism that affected the Paraná Basin in the Lower Cretaceous. Coetaneous volcanic rocks of the Posadas Formation are also exposed in Africa. Taken as a whole, these effusions constitute the Paraná-EtendekaAngola Province (Bellieni et al., 1984a; Marzoli et al., 1999). All of these lava flows, dikes and sills are considered to be representative of the volcanism that was active prior to the opening of the South Atlantic, and they have been associated with the initial stages of the rifting process that generated the separation of South America from Africa (Bellieni et al., 1984a; Piccirillo and Melfi, 1988; Renne et al., 1992a).

We report here new petrographic, geochemical, rock magnetic and paleomagnetic data on lavas sampled in the Misiones Province, Argentina and discuss these results together with previous data obtained from Brazil and Paraguay.

\section{Geological Setting}

The first paleomagnetic and radioisotopic studies of the Paraná Basin basalts were made in the 1960s (Creer, 1962).

Copyright (c) The Society of Geomagnetism and Earth, Planetary and Space Sciences (SGEPSS); The Seismological Society of Japan; The Volcanological Society of Japan; The Geodetic Society of Japan; The Japanese Society for Planetary Sciences; TERRAPUB
Based on these data, a number of researchers proposed that the initial volcanism occurred during the Jurassic age (Creer et al., 1965; Amaral et al., 1966; Valencio and Vilas, 1970; Herz, 1977). Other radiometric aging analyses suggested that the age of the main effusion in Brazil extends from 140 to 120 Ma (Cordani et al., 1980; Mantovani et al., 1985; Piccirillo et al., 1987), with the main eruptive phase taking place in the Early Cretaceous between 135 and 130 Ma (Rocha-Campos et al., 1988; Ernesto and Pacca, 1988). More recently, ${ }^{40} \mathrm{Ar} /{ }^{39} \mathrm{Ar}$ radiometric (133-130 Ma) and paleomagnetic data revealed that only a few million years were required for the emplacement of the major part of the igneous rocks in the Paraná Basin (Renne et al., 1992a, 1992b, 1996a, 1996b, 1997; Ernesto et al., 1999). Turner et al. (1994) suggested that the Paraná-Etendeka continental flood basalts erupted over 10 million years ago, between 137 and $127 \mathrm{Ma}$.

The regional variation in the composition of the lavas indicates that different sources and mechanisms were involved in magma generation. This would be related to the presence of a thermal anomaly in the deep mantle under South America that produced extension while western Gondwana was moving towards the northwest. This thermal anomaly is related to the Tristan da Cunha plume (Renne et al., 1992a).

\section{Petrography and Geochemistry}

The Paraná Magmatic Province (PMP) is geographically divided into three major parts - northern, central and southern - by the Río Piquiri and Río Uruguay tectonic lineaments (Fig. 1(a)). This division is in accordance with petrological and geochemical features (Piccirillo and Melfi, 


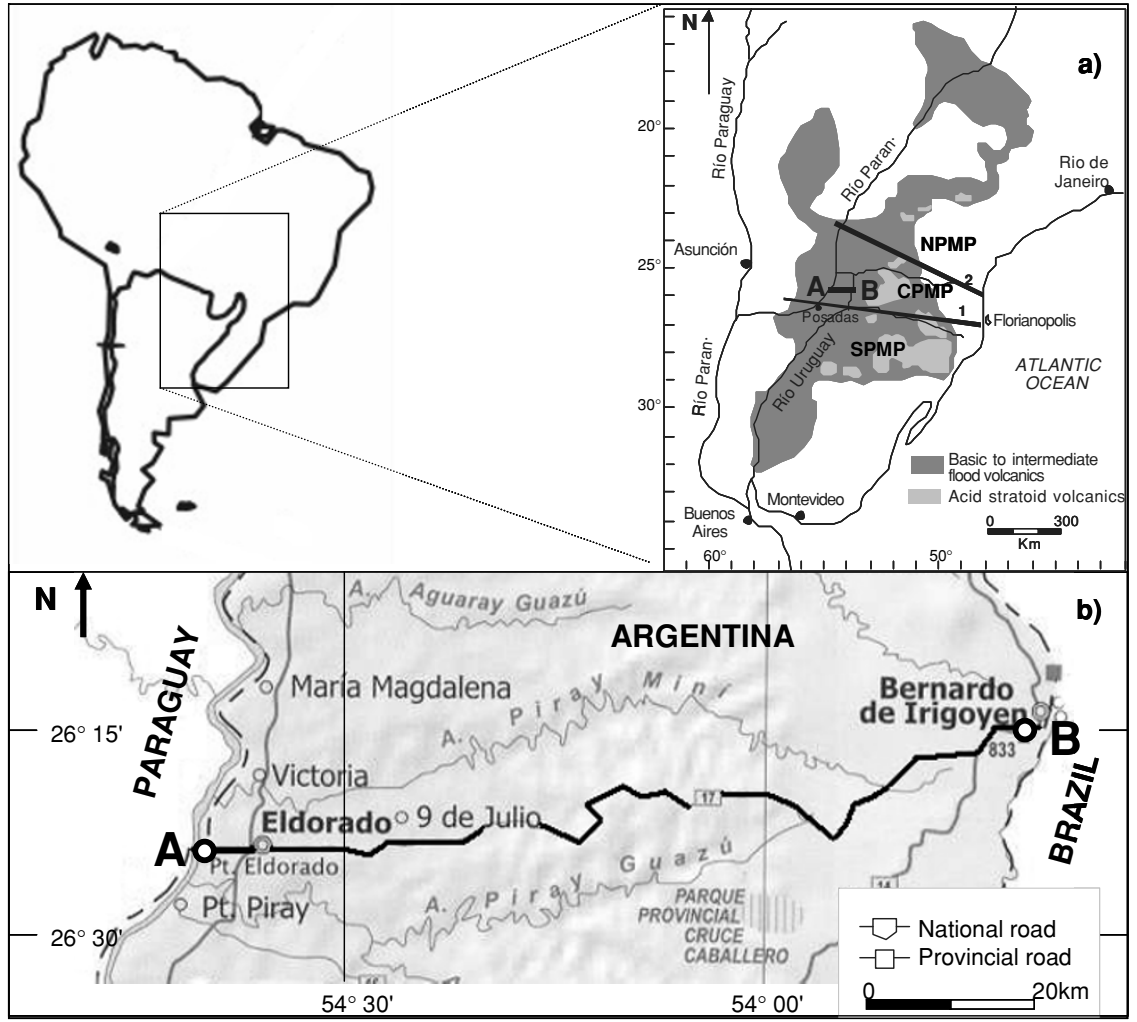

Fig. 1. (a) Sketch map of Paraná flood basalts. Thick straight lines indicate Río Uruguay (1) and Río Piquiri (2) tectonic lineaments which divide the Paraná Magmatic Province into three mayor parts: northern (NPMP), central (CPMP) and southern (SPMP), (after Piccirillo and Melfi, 1988); A-B: sampling section. (b) Sketch map of Misiones province, Argentina, with sampling section from site 0 at A to site 37 at the B position.

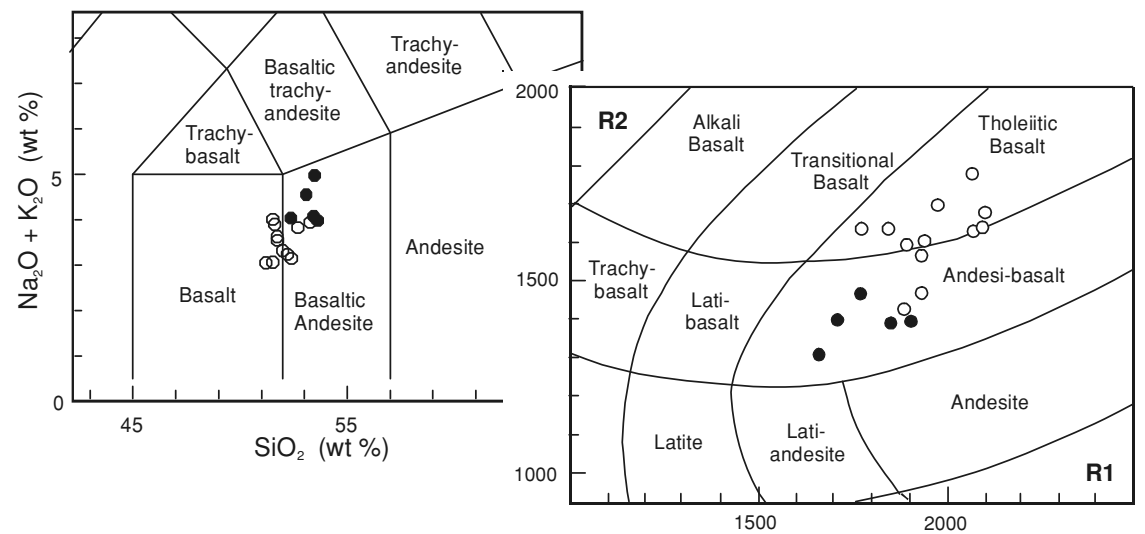

Fig. 2. Classification diagrams of the volcanic rocks from Misiones corresponding to the present study. (a) TAS (Total Alkali-Silica diagram, Le Bas et al., 1986). (b) R1-R2 (De La Roche et al., 1980; Bellieni et al., 1981). R1=4Si-11(Na+K)-2(Fe+Ti), R2=6Ca+2Mg+Al. Filled and open circles, High-Ti and low-Ti rocks, respectively, according to Bellieni et al. (1984b).

1988). In the present study, petrological and geochemical studies were carried out on samples collected along the Eldorado-Bernardo de Irigoyen road cut. The sampling area is located in the central part of the PMP (Fig. 1(b)). The lava flows at this location are massive to amygdaloidal with peperitic levels locally intercalated (Lagorio and Leal, 2005); this clearly demonstrates the close interaction between effusive and sedimentary processes. It should also be noted that several textural variations were verified based on their positions inside the flow.

Major and trace elements were determined at the University of Trieste using an XRF spectrometer and proce- dures developed by Philips (1994) for the correction of matrix effects. Major element abundances were recalculated to $100 \%$ on a volatile-free basis; $\mathrm{FeO}$ was obtained by titration and loss of ignition, corrected for $\mathrm{FeO}$ oxidation gravimetrically. The analytical uncertainties were estimated to be less than 5 and $10 \%$ for major and trace elements, respectively. Rare Earth Elements (REE), Th, Ta, Hf, U and Ga of selected specimens were measured by inductively coupled mass spectrometry (IC-MS) at the Atclabs Laboratory (Canada). Representative data of the whole sample analyzed are given in Table 1 .

Based on the TAS (Total Alkali-Silica) diagram the an- 
Table 1. Representative major ${ }^{\mathrm{a}}$ and trace element composition of volcanic rocks from the study area.

\begin{tabular}{|c|c|c|c|c|c|c|c|c|}
\hline Sample & M64 & M69 & M71 & M77 & M79 & M80 & M83 & M87 \\
\hline Rock & $A B$ & ThB & $A B$ & ThB & ThB & ThB & $A B$ & ThB \\
\hline \multirow[t]{2}{*}{ Type } & Pnp & $\mathrm{Rbr}$ & Pnp & $\mathrm{Rbr}$ & Pnp & Pnp & Pnp & $\mathrm{Rbr}$ \\
\hline & $\mathrm{ITi}$ & LTi & ITi & LTi & $\mathrm{ITi}$ & $\mathrm{ITi}$ & $\mathrm{ITi}$ & LTi \\
\hline $\mathrm{SiO}_{2}$ & 53.53 & 51.27 & 53.57 & 51.80 & 51.84 & 51.60 & 52.28 & 51.68 \\
\hline $\mathrm{TiO}_{2}$ & 2.21 & 1.58 & 2.18 & 1.61 & 1.97 & 1.75 & 1.77 & 1.66 \\
\hline $\mathrm{Al}_{2} \mathrm{O}_{3}$ & 13.11 & 14.25 & 12.88 & 14.25 & 14.39 & 15.35 & 14.07 & 15.55 \\
\hline $\mathrm{FeO}$ & 14.06 & 11.95 & 14.23 & 11.78 & 12.74 & 11.85 & 12.27 & 11.52 \\
\hline $\mathrm{MnO}$ & 0.21 & 0.17 & 0.18 & 0.20 & 0.19 & 0.17 & 0.20 & 0.18 \\
\hline $\mathrm{MgO}$ & 3.56 & 6.31 & 3.29 & 5.91 & 4.85 & 4.80 & 5.76 & 5.13 \\
\hline $\mathrm{CaO}$ & 8.89 & 11.15 & 8.34 & 10.56 & 10.15 & 10.18 & 10.10 & 10.11 \\
\hline $\mathrm{Na}_{2} \mathrm{O}$ & 2.66 & 2.31 & 2.47 & 2.24 & 2.38 & 2.79 & 2.29 & 2.78 \\
\hline $\mathrm{K}_{2} \mathrm{O}$ & 1.43 & 0.74 & 2.51 & 1.39 & 1.17 & 1.22 & 0.95 & 1.12 \\
\hline $\mathrm{P}_{2} \mathrm{O}_{5}$ & 0.34 & 0.27 & 0.34 & 0.25 & 0.32 & 0.28 & 0.30 & 0.26 \\
\hline sum & 100.00 & 100.00 & 100.00 & 100.00 & 100.00 & 100.00 & 100.00 & 100.00 \\
\hline $\mathrm{mg \#}$ & 0.34 & 0.52 & 0.32 & 0.50 & 0.44 & 0.45 & 0.49 & 0.47 \\
\hline L.O.I. & 0.92 & 2.77 & 1.50 & 2.50 & 4.71 & 1.76 & 2.70 & 2.88 \\
\hline $\mathrm{FeO}$ & 4.40 & 5.23 & 1.59 & 6.93 & 0.90 & 2.36 & 0.87 & 1.48 \\
\hline $\mathrm{Fe}_{2} \mathrm{O}_{3}$ & 10.72 & 7.46 & 14.03 & 5.38 & 13.14 & 10.53 & 12.66 & 11.14 \\
\hline $\mathrm{Cr}$ & 74 & 177 & 79 & 178 & 112 & 115 & 145 & 135 \\
\hline $\mathrm{Ni}$ & 38 & 75 & 39 & 76 & 55 & 68 & 70 & 75 \\
\hline $\mathrm{Rb}$ & 37 & 17 & 106 & 31 & 17 & 26 & 18 & 18 \\
\hline $\mathrm{Ba}$ & 318 & 252 & 337 & 269 & 363 & 327 & 296 & 290 \\
\hline $\mathrm{Sr}$ & 251 & 354 & 280 & 332 & 404 & 401 & 330 & 355 \\
\hline $\mathrm{Nb}$ & 19 & 15 & 17 & 13 & 14 & 16 & 13 & 14 \\
\hline $\mathrm{Zr}$ & 239 & 143 & 204 & 142 & 171 & 157 & 153 & 137 \\
\hline $\bar{Y}$ & 38 & 20 & 29 & 23 & 24 & 24 & 28 & 24 \\
\hline $\mathrm{La}$ & $22,60^{*}$ & 19 & 24 & $14,60^{*}$ & 24 & 19 & $16,40^{*}$ & 19 \\
\hline $\mathrm{Ce}$ & 46.70 & 38 & 50 & 30.60 & 53 & 49 & 34.00 & 43 \\
\hline $\operatorname{Pr}$ & 5.93 & & & 3.89 & 28 & & 4.26 & \\
\hline $\mathrm{Nd}$ & 27.40 & 22 & 25 & 17.60 & & & 20.10 & 20 \\
\hline Sm & 6.51 & & & 4.18 & & & 4.78 & \\
\hline $\mathrm{Eu}$ & 2.03 & & & 1.44 & & & 1.60 & \\
\hline Gd & 6.90 & & & 4.21 & & & 4.95 & \\
\hline $\mathrm{Tb}$ & 1.24 & & & 0.76 & & & 0.85 & \\
\hline Dy & 7.48 & & & 4.35 & & & 5.14 & \\
\hline $\mathrm{Ho}$ & 1.49 & & & 0.87 & & & 1.02 & \\
\hline $\mathrm{Er}$ & 4.23 & & & 2.54 & & & 2.92 & \\
\hline $\mathrm{Tm}$ & 0.61 & & & 0.34 & & & 0.43 & \\
\hline $\mathrm{Yb}$ & 4.02 & & & 2.34 & & & 2.74 & \\
\hline Lu & 0.59 & & & 0.34 & & & 0.41 & \\
\hline $\mathrm{Hf}$ & 5.20 & & & 3.10 & & & 3.50 & \\
\hline $\mathrm{Ta}$ & 0.96 & & & 0.62 & & & 0.66 & \\
\hline Q (norm.) & 5.83 & 1.19 & 4.34 & 1.28 & 3.00 & 0.49 & 3.60 & 0.52 \\
\hline Hy (norm.) & 17.19 & 20.23 & 16.63 & 19.46 & 18.68 & 17.67 & 20.84 & 18.67 \\
\hline $\mathrm{Ti} / \mathrm{Y}$ & 349 & 474 & 451 & 420 & 492 & 438 & 379 & 415 \\
\hline $\mathrm{Ti} / \mathrm{Zr}$ & 55 & 66 & 64 & 68 & 69 & 67 & 69 & 73 \\
\hline $\mathrm{Zr} / \mathrm{Y}$ & 6,3 & 7,2 & 7,0 & 6,2 & 7,1 & 6,5 & 5.5 & 5.7 \\
\hline
\end{tabular}

${ }^{a}$ Major elements were recalculated to $100 \%$ on a volatile-free basis. $\mathrm{mg}, \mathrm{Mg} /(\mathrm{Mg}+\mathrm{Fe} 2+)$ and $\mathrm{CIPW}$-normative compositions assuming $\mathrm{Fe}_{2} \mathrm{O}_{3} / \mathrm{FeO}=0.15$; $\mathrm{Q}$ and $\mathrm{Hy}, \mathrm{CIPW}$-normative quartz and hypersthene, respectively. Trace element contents in normal type and and italics indicate measurements by XRF and ICP-MS, respectively. AB, Andesibasalt; ThB, tholeiitic basalt; ITi, intermediate-Ti; LTi, low-Ti; Pnp, Paranapanema-type; Rbr, Ribeira-type.

alyzed rocks can be classified as basalts and basaltic andesites (Le Bas et al., 1986; Fig. 2(a)). In the R1-R2 diagram they plot as tholeiitic basalts and andesi-basalts (De La Roche et al., 1980; Bellieni et al., 1981; Fig. 2(b)).

The different lava flows show middle to coarse intergranular or intersertal textures to weakly microporphyritic/porphyritic textures (Fig. 3). The latter varieties are composed of microphenocrysts and/or phenocrysts of

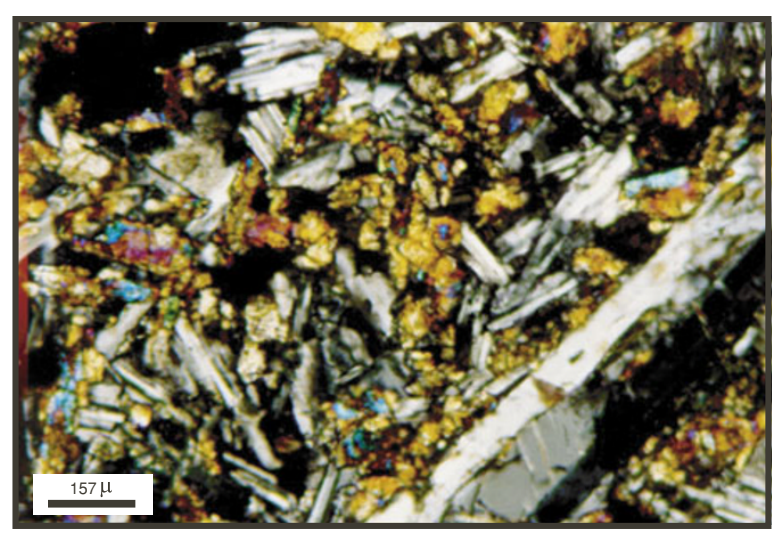

Fig. 3. Photomicrograph, in cross-polarized light, of a basaltic andesite with porphyritic texture. A phenocryst of plagioclase and a microphenocryst of titanomagnetite (upper left corner) are set in an intergranular groundmass.

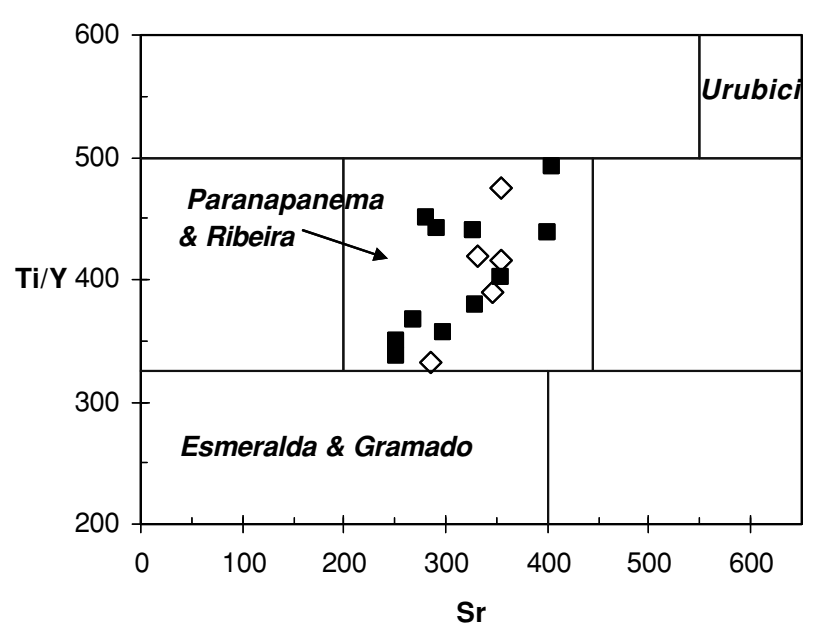

Fig. 4. Sr versus Ti/Y diagram, to discriminate the diverse magma types defined by Peate et al. (1992), (see text for explanation). Filled squares, Paranapanema-type; open diamonds, Ribeira-type. Fields corresponding to Urubici, Esmeralda and Gramado types are also shown; Pitanga magma type was not taken into account because of $\mathrm{TiO}_{2}$ contents lower than $2.8 \mathrm{wt} \%$ of the studied rocks.

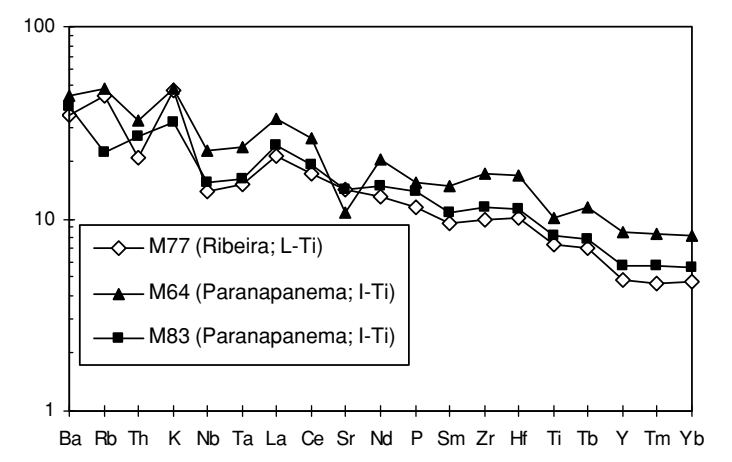

Fig. 5. Primitive mantle (Sun and McDonough, 1989) normalized multi-elemental plots for representative rocks from the study area.

plagioclase $\left(\mathrm{An}_{65-50}\right)$, augite, opaque minerals, olivine (frequently altered to iddingsite and/or bowlingite) and pigeonite. The groundmass is made of the same phases, also showing intergranular/interstitial textures; interstitial potas- 

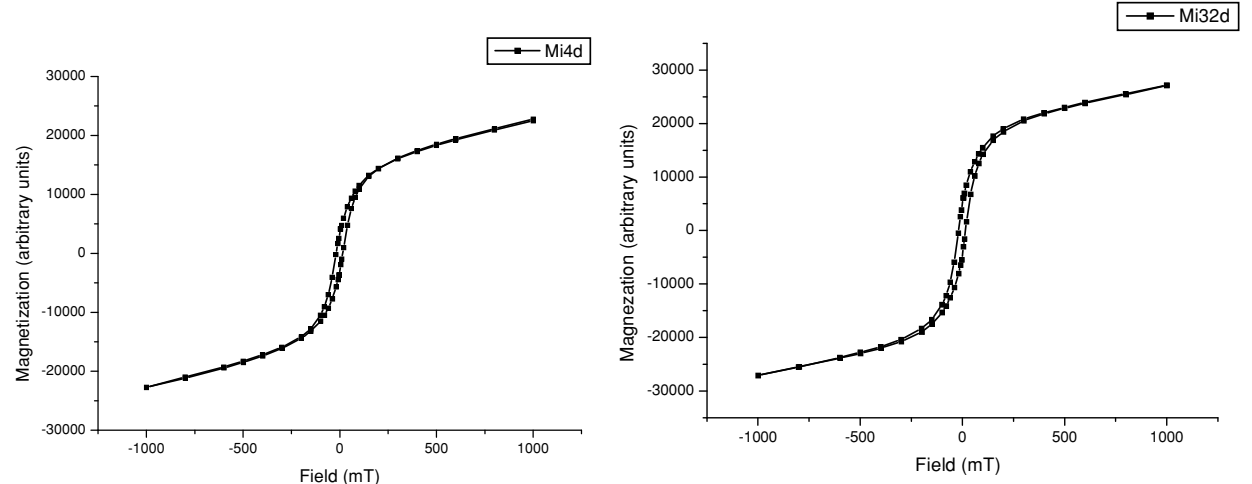

Fig. 6. Typical hysteresis loops for specimens representative of the lower (Mi4d, site 4) and of the upper (Mi32d, site 32) lava flows.

Table 2. Volume magnetic susceptibility $(\chi)$ and $F$ factors for the specimens.

\begin{tabular}{|c|c|c|}
\hline Sample & $\chi_{\mathrm{E}-5} \mathrm{SI}$ & $F$ factor \\
\hline Mi0d & 588 & 1.0 \\
\hline Mild & 40 & 5.0 \\
\hline $\mathrm{Mi} 2 \mathrm{~d}$ & 2542 & 0.0 \\
\hline Mi3d & 1410 & 0.6 \\
\hline Mi4d & 270 & 6.7 \\
\hline Mi6d & 2498 & 0.2 \\
\hline Mi7d & 3260 & 1.5 \\
\hline Mi8d & 2658 & 0.7 \\
\hline Mi9d & 1552 & 0.9 \\
\hline Mi10d & 3341 & 0.2 \\
\hline Mi11d & 2482 & 0.7 \\
\hline Mi12d & 1400 & 0.3 \\
\hline Mi13d & 800 & 0.0 \\
\hline Mi14d & 1302 & 0.5 \\
\hline Mi15d & 1174 & 1.4 \\
\hline Mi16d & 2468 & 0.9 \\
\hline Mi17d & 3494 & 0.7 \\
\hline Mi18d & 5842 & 0.7 \\
\hline Mi19d & 4898 & 0.6 \\
\hline Mi20d & 650 & 3.7 \\
\hline Mi21d & 430 & 0.5 \\
\hline Mi22d & 308 & 3.9 \\
\hline Mi24d & 80 & 5.0 \\
\hline Mi25d & 74 & 10.8 \\
\hline Mi26d & 1940 & 0.6 \\
\hline Mi27d & 3176 & 0.3 \\
\hline Mi29d & 3354 & 1.7 \\
\hline Mi30d & 1686 & 1.4 \\
\hline Mi31d & 984 & 0.8 \\
\hline Mi32d & 734 & 7.1 \\
\hline Mi33d & 1452 & 0.3 \\
\hline Mi34d & 1684 & 0.7 \\
\hline Mi35d & 1482 & 0.5 \\
\hline Mi36d & 2392 & 1.0 \\
\hline Mi37d & 2012 & 0.0 \\
\hline
\end{tabular}

sium feldspar and accessory apatite frequently occur. Glass may be fresh or replaced by celadonitic products. Calcite-, quartz-, celadonite- and siliceous-zeolites bearing amygdales may be sparsely present.

On the basis of their optical characteristics, opaque minerals correspond mainly to titanomagnetite and, to a lesser degree, ilmenite. Magnetite grains show a slight alteration to haematite. While the titanomagnetite crystals usually display dimensions up to $0.55 \mathrm{~mm}$ (as can be seen in Fig. 3), in some rocks they present two contrasting modal sizes: $0.7-$ $1.2 \mathrm{~mm}$ and less than $0.15 \mathrm{~mm}$. Very small crystal sec-

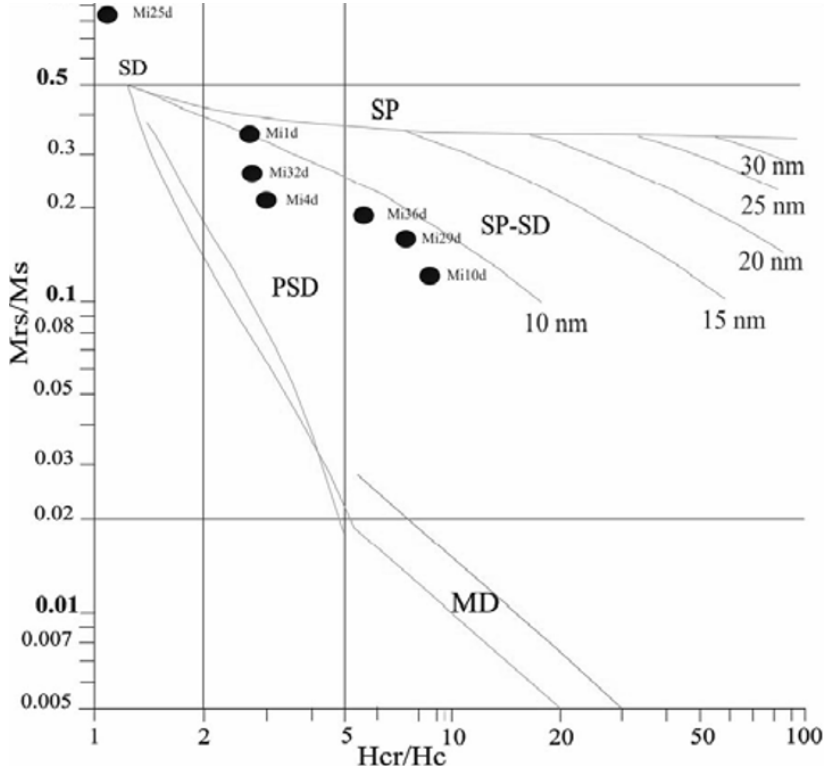

Fig. 7. Hysteresis data of Posadas Formation samples. Grain size determination according to Dunlop (2002).

tions also appear, both as inclusions in plagioclase and/or clinopyroxene crystals, in the vitreous groundmass.

Based on Bellieni et al. (1984b), Paraná tholeiitic rocks have essentially been grouped into two main rock types on the basis of their $\mathrm{TiO}_{2}$ content: low-Ti basalts with $\mathrm{TiO}_{2}$ $<2 \mathrm{wt} \%$, and high-Ti basalts bearing $\mathrm{TiO}_{2}>2 \mathrm{wt} \%$. While northern PMP is dominated by rocks of high-Ti content, southern PMP is characterized by low-Ti basalts, while in the central part both types have been verified (Piccirillo and Melfi, 1988). More recently, various researchers (e.g. Peate et al., 1992) have distinguished six distinct magma types that broadly correspond to the earlier classification: Gramado, Esmeralda and Ribeira types were defined as lowTi basalts, and Paranapanema, Pitanga and Urubici types as high-Ti varieties. Nevertheless, Paranapanema is in fact considered to be intermediate Ti rocks. It should be noted that in this classification the low-Ti lavas can contain up to $2.3 \mathrm{wt} \% \mathrm{TiO}_{2}$ while the intermediate and high-Ti varieties may display as little as $1.7 \% \mathrm{TiO}_{2}$. Samples falling in between this overlapping zone can distinguished by taking other compositional parameters into account, such as $\mathrm{Ti} / \mathrm{Zr}$, 

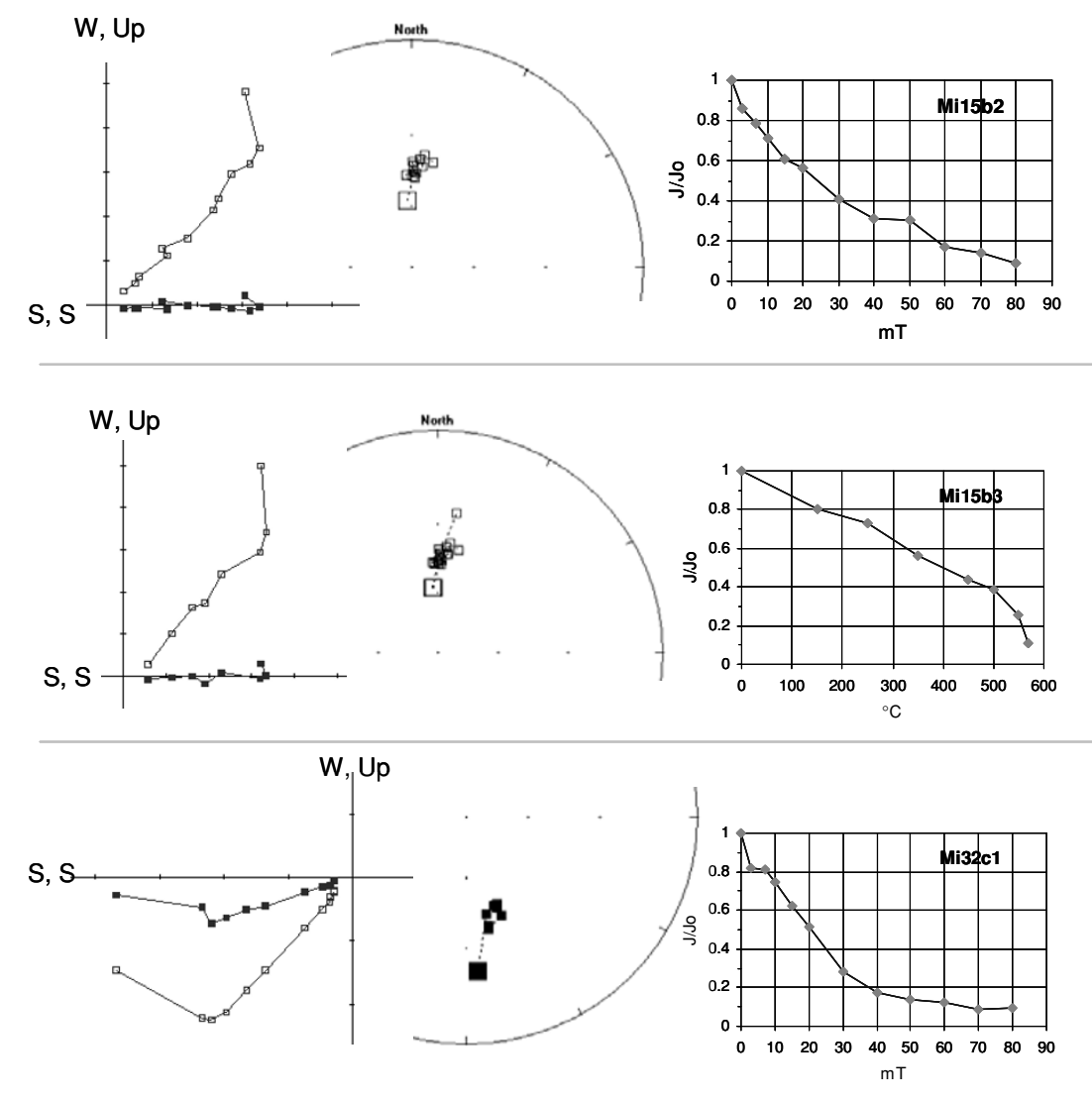

Fig. 8. Orthogonal plots, stereoplots, and magnetic intensity curves for demagnetization of representative specimens. In orthogonal plots, open (solid) squares indicate projection onto the vertical (horizontal) plane. In stereoplots, open (solid) squares indicate projection onto the upper (lower) hemisphere.

Ti/Y, Zr/Y ratios and Sr content (Peate et al., 1992).

According to the latter classification, the rocks of this study correspond to Paranapanema (intermediate-Ti) and Ribeira (low-Ti) types, as can be seen in Fig. 4; this classification is in agreement with the coexistence of rocks with variable Ti content in the central region of the Paraná Basin (Piccirillo and Melfi, 1988). The Ribeira type is distinguishable from the Paranapanema variety by its lower $\mathrm{TiO}_{2}$ content $(1.5-1.7 \mathrm{wt} \%$ vs. $>1.7 \mathrm{wt} \%$, respectively). In all cases, a $\mathrm{TiO}_{2}$ content of less than $2.8 \mathrm{wt} \%$ excludes the presence of the Pitanga type.

The multi-elemental diagrams normalized to the primordial mantle of Sun and McDonough (1989) show Nb-Ta and Sr negative anomalies that are typical of the tholeiitic continental lava flows (Fig. 5). A negative $\mathrm{Sr}$ anomaly is particularly striking in the sample of Parapanema variety with a higher $\mathrm{TiO}_{2}$ content $\left(M_{64}=2.21 \mathrm{wt} \%\right)$. Compared with the sample of the Ribeira variety (low-Ti), this sample contains the highest content of most of the incompatible elements, with the exception of $\mathrm{Ba}, \mathrm{Rb}$ and $\mathrm{K}$ (Fig. 5).

The stratigraphic sequence of the geochemical types shown here is based on systematic studies of the profiles taken from exploratory wells in Paraná Basin, Brazil. From the lower to the upper flows the sequence is formed by the Gramado (locally interbedded with Urubici-type flows), Esmeralda, Ribeira, Pitanga and Paranapanema units (Peate $e t$ al., 1992). Therefore, the studied lavas correspond to two of the three younger units of the sequence.

\section{Paleomagnetic Study}

A paleomagnetic and rock-magnetic study was carried out on diverse lava flows and dikes from the Posadas Formation in Misiones, Argentina. Hand samples were collected along road cuts between Puerto Eldorado and Bernardo de Irigoyen (Fig. 1(b)). The lava flow sequence is well exposed in this location, and the sampling was facilitated by the steep slopes, controlled by the sub-horizontal position of the basaltic flows. Thirty-four lava flows and three sills were recognized. Neither the upper or lower contacts could be identified. Individual flows were determined by their physical characteristics, such as the presence of vesicles, grain size and joints. Since these lava flows were extruded on a previous relief, their stratigraphic positions are not necessarily indicative of their relative age. Therefore, it is possible that among the sampled flows, units may have been sampled more than once. In some places it was impossible to collect hand samples or to uniquely identify the units because the outcrops were highly weathered. Each identified unit was considered to be a site, and hand samples were collected at each site. We drilled at least three cylindrical specimens (diameter: $2.54 \mathrm{~cm}$; height: $2.2 \mathrm{~cm}$ ) of each sample.

\section{Magnetic Properties}

Magnetic susceptibility measurements at room temperature and at two frequencies $(470 \mathrm{~Hz}$ and $4700 \mathrm{~Hz})$ were carried out using a Bartington MS2 susceptibility meter. $F$ 

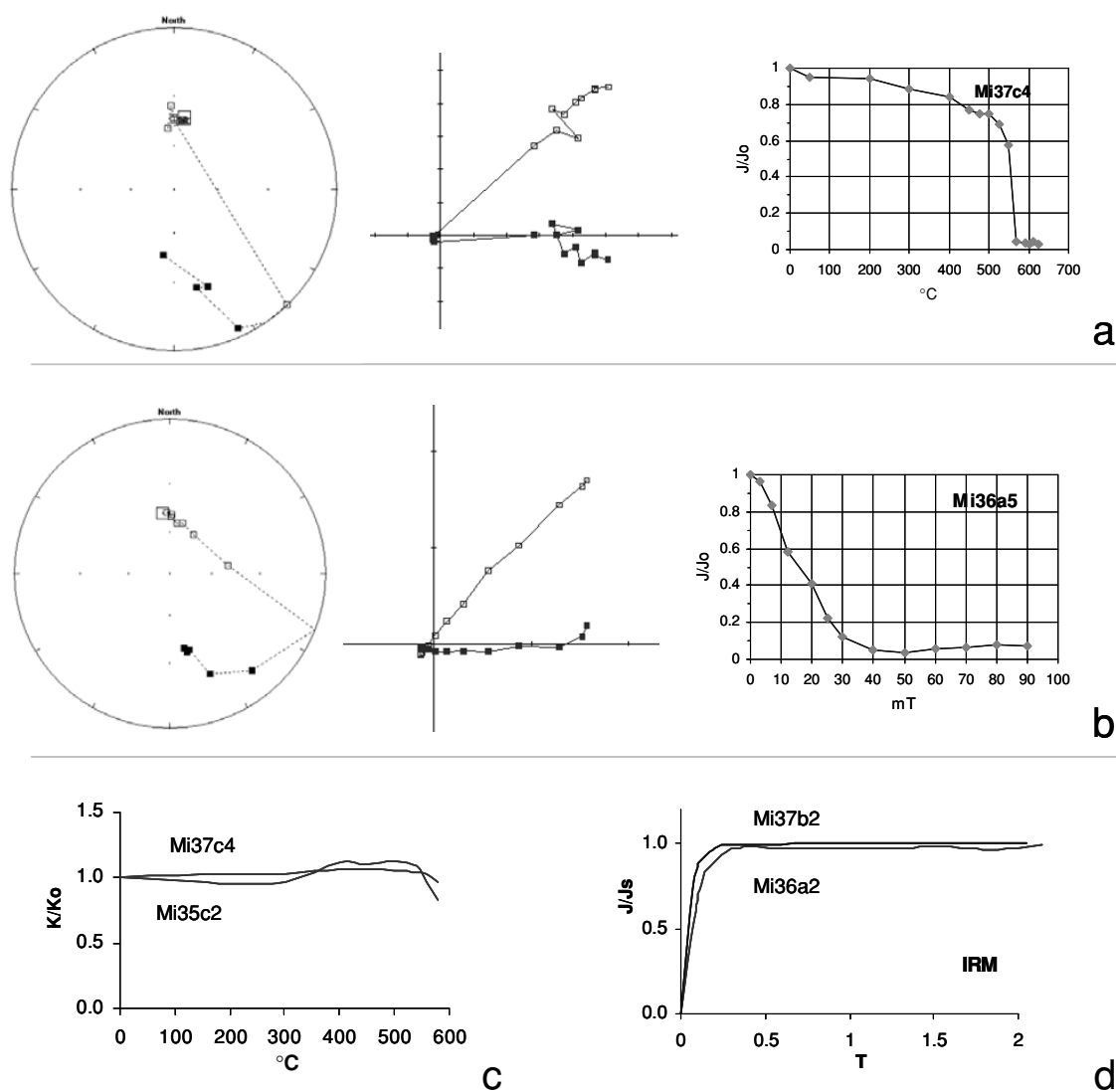

d

Fig. 9. (a) and (b) Stereoplots, orthogonal plots, and magnetic intensity curves for demagnetization of two representative specimens. (c) Normalized susceptibility vs. temperature for the thermal demagnetization. (d) Curves of isothermal remanent magnetization acquisition.
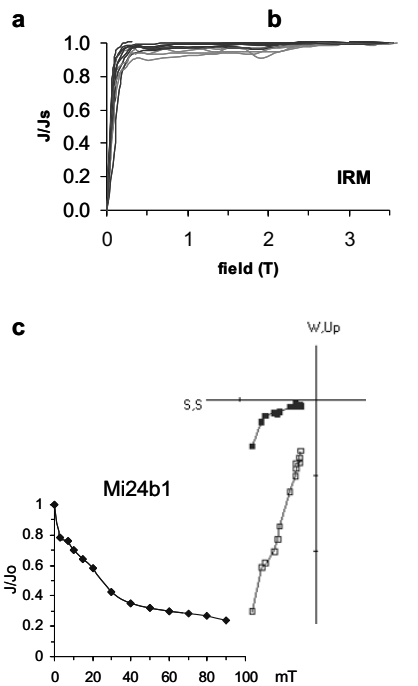
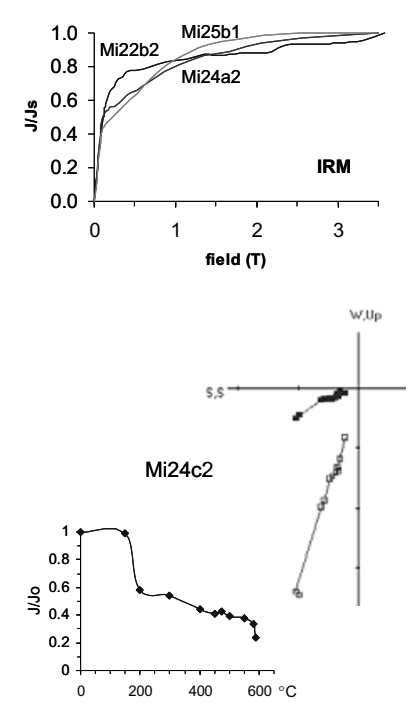

Fig. 10. Curves of isothermal remanent magnetization acquisition for: (a) specimens from lava flows, (b) specimens from dikes. (c) Demagnetization behavior for the same dike specimens.

factors $\left[100\left(\chi_{\text {lower }}-\chi_{\text {high }}\right) / \chi_{\text {low }}\right)$ higher than $6 \%$ were obtained in some specimens (Table 2). These values suggest the presence of superparamagnetic particles (SP) of sizes near 30.10 ${ }^{-9} \mathrm{~m}$ (Dunlop and Özdemir, 1997; Maher and Thompson, 1999; Evans and Heller, 2003, among others).

Hysteresis loops for different representative lithologies

were determined. The coercivity of remanence $\left(H_{c r}\right)$ was calculated from isothermal remanent magnetization (IRM) and back field measurements using a Vibrating Sample Magnetometer (VSM, Molspin). The magnetic parameters obtained in these cycles are presented in Table 3 . The coercivity values indicate that the dominant magnetic mineral is magnetite (Dankers, 1978; Roberts et al., 1995). The shape of the hysteresis loops is typical of single-domain (SD)- to pseudo-single-domain (PSD)-sized magnetite (Fig. 6).

The ratio of the hysteresis parameters $M_{r s} / M_{s}$ vs. $H_{c r} / H_{c}$ are plotted in Fig. 7. The magnetite particles have a size between pseudo single domain (PSD) and single domain (SD) according to Dunlop (2002). $H_{c r} / H_{c}$ values observed in samples Mi10d, Mi29d and Mi36d could indicate a bimodal grain size of magnetite and / or the presence of a high coercivity mineral, probably haematite. In these samples, the coarser particles would constitute an overwhelmingly large fraction of the total volume of magnetite (Parry, 1982).

\section{Paleomagnetic Results}

To analyze the stability of the magnetic remanence, we subjected the specimens to alternating field (AF) and thermal detailed demagnetization techniques. Remanent magnetization measurements and demagnetizations were made with a Digico modified spinner, a $2 \mathrm{G}$ cryogenic magnetometer and a Schonstedt furnace.

Thermal demagnetization was performed in 15 steps from $100^{\circ} \mathrm{C}$ up to $620^{\circ} \mathrm{C}$. Possible mineralogical changes were controlled by measuring the bulk susceptibility after 
Table 3. Magnetic parameters ${ }^{\mathrm{a}}$ for representative specimens.

\begin{tabular}{cccccccccc}
\hline Sample & $\begin{array}{c}M_{r s} \\
\left(\mathrm{E}^{-9} \mathrm{Am}^{2} / \mathrm{kg}\right)\end{array}$ & $\begin{array}{c}M_{s} \\
\left(\mathrm{E}^{-9} \mathrm{Am}^{2} / \mathrm{kg}\right)\end{array}$ & $H_{c r}(\mathrm{mT})$ & $H_{c}(\mathrm{mT})$ & $M_{r s} / M_{s}$ & $H_{c r} / H_{c}$ & $\% \chi_{\mathrm{pa}}$ & $\% \chi_{\mathrm{fe}}$ \\
& 1.17 & 3.31 & 43.66 & 18.15 & 0.35 & 2.40 & 10.36 & 89.60 \\
Mi1d & 18.54 & 83.15 & 49.78 & 17.69 & 0.22 & 2.81 & 4.43 & 95.57 \\
Mi4d & 46.81 & 371.17 & 41.30 & 5.70 & 0.12 & 7.24 & 0.35 & 99.65 \\
Mi10d & 1.30 & 1.48 & 24.36 & 23.66 & 0.87 & 1.02 & 6.13 & 93.87 \\
Mi25d & 30.37 & 213.32 & 35.92 & 5.70 & 0.14 & 6.30 & 1.26 & 98.74 \\
Mi29d & 28.40 & 116.11 & 39.87 & 17.04 & 0.24 & 2.33 & 2.47 & 97.53 \\
Mi32d & 63.26 & 367.7 & 45.37 & 8.75 & 0.17 & 5.18 & 0.92 & 99.08 \\
Mi36d & & 367 & & & & & & \\
\hline
\end{tabular}

${ }^{\mathrm{a}} M_{r s}$, Saturation remanence; $M_{s}$, saturation magnetization; $H_{c r}$, coercivity of remanence; $H_{c}$, coercive force; $\% \chi_{\mathrm{pa}}$, percentage paramagnetic susceptibility; $\% \chi_{\mathrm{fe}}$, percentage ferromagnetic susceptibility.

each step. Only a few samples retained $10 \%$ of their initial remanences at temperatures of $610^{\circ} \mathrm{C}$. Remanence was generally removed between $570^{\circ}$ and $580^{\circ} \mathrm{C}$, indicating that the main remanence carriers are titanomagnetites (virtually Ti-poor magnetite).

AF demagnetization was applied in 13 steps from 5 to $100 \mathrm{mT}$. Many specimens presented a soft viscous remanence of low intensity that was easily removed in 5- to 10mT fields (Fig. 8). This behavior could imply the presence of either grains with low relaxation times of very small sizes or of multi-domain (MD) grains. After the elimination of the viscous component, most of the specimens showed a decay of the magnetization toward the origin, which is typical of a stable single component (Fig. 8). The samples from the bottom and the top of the profile have a stable component with negative inclination. The samples with intermediate positions have a stable component with positive inclination.

Few samples from the upper lava flows showed bicomponent magnetizations (Fig. 9(a) and (b)): (1) a normal polarity component with a direction coincident with those of the lower lava flows and (2) a reverse polarity component almost antipodal to the other. The normal component presents low coercivity and unblocking temperatures of $450-570^{\circ} \mathrm{C}$, suggesting that it is carried by grains of Ti-poor titanomagnetite. The reverse component is defined only in the last steps of thermal and magnetic demagnetization, and its high coercivity and low intensity suggest that haematite is the carrier (Fig. 9(a) and (b)). Given that the direction of the reverse components is antipodal to that of the normal component, it is most probable that haematite was formed in a early stage of oxidation, very near in time to the extrusion, but after a polarity change in the geomagnetic field. The susceptibility values measured after each thermal demagnetization step did not change, indicating that new minerals were not generated (Fig. 9(c)). Because of the low proportion of haematite to titanomagnetite the former mineral is not evident in the IRM acquisition curves (Fig. 9(d)). The remanence directions isolated by AF and thermal demagnetization are coincident in all cases.

IRM studies were performed by applying fields between 0.05 and 3.5 tesla on one specimen of each site after demagnetization. Most of the specimens reached saturation at fields less than $300 \mathrm{mT}$, indicating that the remanence is carried by magnetite (Fig. 10(a)), and only specimens from the dikes (sites 22, 24 and 25) presented magnetizations that did not saturate at the applied fields (Fig. 10(b)). This sug-
Table 4. Paleomagnetic results for the Posadas Formation ${ }^{\mathrm{a}}$.

\begin{tabular}{|c|c|c|c|c|c|c|c|}
\hline Site & $D$ & $I$ & alfa95 & $N$ & VGP lat & VGP long & $h$ \\
\hline 0 & 19.4 & -35.2 & 3.7 & 5 & -70.8 & 198.1 & 100 \\
\hline 1 & 26.0 & -43.4 & 11.4 & 4 & -66.6 & 218.7 & 110 \\
\hline 2 & 13.7 & -40.7 & 10.5 & 6 & -77.2 & 204.3 & 130 \\
\hline 3 & 354.9 & -55.1 & 7.4 & 5 & -79.8 & 329.4 & 240 \\
\hline 4 & 349.4 & -45.3 & 9.9 & 4 & -80.5 & 30.6 & 260 \\
\hline 5 & 181.9 & 40.7 & 7.4 & 2 & 86.4 & 335 & 230 \\
\hline 6 & 6.2 & -39.7 & 7.8 & 4 & -83.2 & 182.6 & 230 \\
\hline 7 & 4.8 & -38.1 & 4.7 & 4 & -83.4 & 167.9 & 230 \\
\hline 8 & 345.9 & -38.9 & 8.9 & 4 & -71.2 & 62.2 & 280 \\
\hline 9 & 0.0 & -41.6 & 8.1 & 5 & -87.5 & 125.6 & 280 \\
\hline 10 & 2.7 & -44.3 & 5.7 & 5 & -87.5 & 207.3 & 300 \\
\hline 11 & 355.0 & -33.1 & 6.3 & 5 & -80.5 & 95.6 & 320 \\
\hline 12 & 351.4 & -37.1 & 5.6 & 6 & -80.3 & 69.5 & 340 \\
\hline 13 & 2.5 & -42.0 & 6.7 & 3 & -86.9 & 173.4 & 340 \\
\hline 14 & 357.7 & -43.1 & 6.0 & 4 & -87.6 & 66.7 & 370 \\
\hline 15 & 358.1 & -46.0 & 3.7 & 4 & -88.0 & 4 & 370 \\
\hline 16 & 358.9 & -45.6 & 3.8 & 6 & -88.8 & 359.7 & 430 \\
\hline 17 & 8.2 & -42.9 & 11.5 & 4 & -82.4 & 206.7 & 430 \\
\hline 18 & 3.5 & -27.4 & 7.0 & 4 & -77.7 & 141.9 & 500 \\
\hline 19 & 5.8 & -29.4 & 5.5 & 5 & -78.1 & 153.9 & 500 \\
\hline 20 & 347.6 & -33.5 & 1.9 & 6 & -76.0 & 68.3 & 500 \\
\hline 21 & 182.8 & 65.7 & 6.9 & 4 & 68.2 & 120.7 & 580 \\
\hline 22 & 202.1 & 80.5 & 12.8 & 2 & 43.1 & 116.4 & 590 \\
\hline 23 & 210.3 & 42.5 & 5.4 & 4 & 62.7 & 38.9 & 640 \\
\hline 24 & 156.6 & 73.5 & 5.2 & 3 & 53.2 & 145.8 & 640 \\
\hline 25 & 179.8 & 74.6 & 5.4 & 2 & 55.1 & 126.2 & 640 \\
\hline 26 & 160.3 & 68.9 & 6.6 & 4 & 60.0 & 150.4 & 670 \\
\hline 27 & 204.3 & 65.0 & 13.5 & 3 & 61.8 & 89.6 & 670 \\
\hline 28 & 190.7 & 29.8 & 5.9 & 3 & 75.7 & 352.2 & 700 \\
\hline 29 & 178.7 & 63.6 & 6.4 & 4 & 71.0 & 128.9 & 700 \\
\hline 30 & 180.2 & 45.3 & 9.9 & 3 & 88.9 & 316.1 & 720 \\
\hline 31 & 156.9 & 44.3 & 5.0 & 6 & 69.3 & 211.8 & 740 \\
\hline 32 & 160.8 & 44.3 & 6.3 & 5 & 72.8 & 212.8 & 740 \\
\hline 33 & 350.9 & -46.6 & 4.5 & 4 & -81.7 & 23 & 780 \\
\hline 34 & 7.5 & -54.8 & 5.3 & 4 & -78.9 & 272.7 & 790 \\
\hline 35 & 359.7 & -43.5 & 5.6 & 5 & -89.1 & 109.3 & 790 \\
\hline 36 & 351.3 & -47.5 & 6.8 & 4 & -81.9 & 17.2 & 800 \\
\hline 37 & 7.2 & -40.7 & 7.8 & 5 & -82.8 & 193.4 & 810 \\
\hline
\end{tabular}

${ }^{a} D, I$, Declination and inclination for the site mean direction, respectively; alfa95, Fisher statistical parameter for this mean; $N$, number of specimens used in the calculation; $h$, approximate elevation of the site $(\mathrm{m})$. 


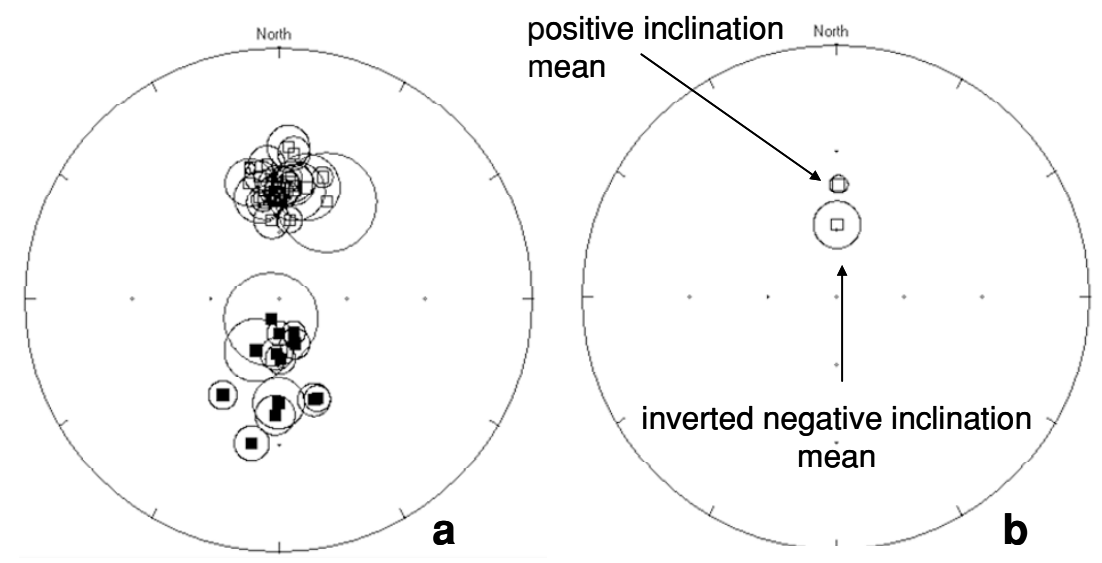

Fig. 11. (a) Stereographic plots for site mean directions with the $\alpha_{95}$ circles. (b) Mean direction for the negative inclination group and inverted mean direction for the positive inclination group. Open symbols, negative inclinations; full symbols, positive inclinations.
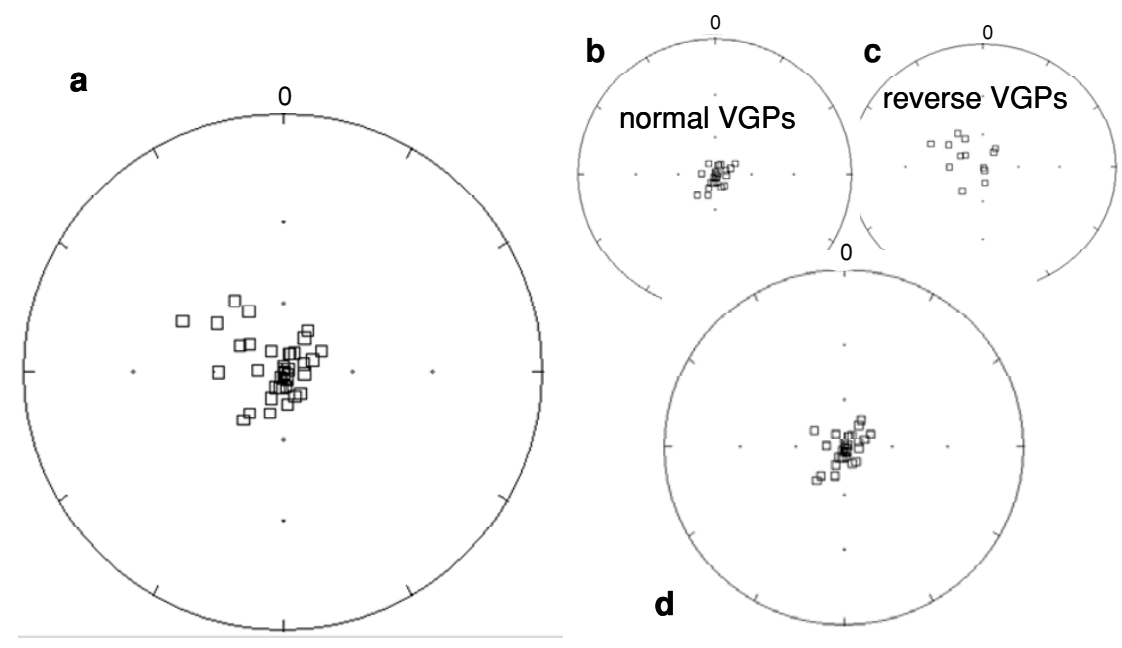

Fig. 12. South virtual geomagnetic poles (VGPs) for Misiones sites (M): (a) VGPs for all the sites, (b) normal polarity VGPs, (c) reverse polarity VGPs, (d) normal polarity VGPs joint to selected reverse VGPs.

gests an important presence of haematite. The magnetic behavior of the specimens of these sites is characterized by the presence of a component with high positive inclination (Fig. 10(c)). It should be noted that the presence of lowTi titanomagnetites, which are the most frequent magnetic carriers, coincide with the petrological descriptions of these tholeiitic basalts.

Characteristic remanent magnetization (ChRM) directions were determined by principal component analysis (Kirschvink, 1980). In most specimens ChRMs were defined with a maximum angular deviation (MAD) smaller than $5^{\circ}$; in all specimens MAD was smaller than $10^{\circ}$. Mean site direction was obtained by averaging the magnetic components of all the specimens using fisherian statistic. The corresponding virtual geomagnetic pole (VGP) was calculated for each mean direction (Table 4).

When the increases in the altitude of the outcrop from site 0 to site 37 are taken into consideration, the polarities of the VGPs would indicate that the sequence has registered at least two polarity reversions. On the lower section, the VGPs have a normal polarity, while in the middle they have reverse polarity, culminating with a group of flows with normal polarity VGPs. A site of reverse polarity is located in the normal initial sequence. This could indicate either another reverse polarity interval or that this site belongs to a younger flow of the reverse series located between the normal polarity lava flows as a result of a paleotopographic effect.

The normal polarity directions form a concentrated group with its mean located at declination $D=1.2^{\circ}$; inclination $I=-41.8^{\circ}$ for $N=25$ sites, and with Fisher parameters $k=68$; alfa95 $=3.5^{\circ}$ (Fig. 11(a)). The directions corresponding to a reverse polarity are more scattered, with a mean at $D=180.7^{\circ} ; I=58.0^{\circ} ; N=13 ; k=19$ and alfa95 $=9.8^{\circ}$ (Fig. 11(a)). Both mean directions are not antipodal, giving a negative reversal test (Fig. 11(b)). Figure 11(a) shows that the positive inclination directions seem to form two groups: one of tightly grouped set of directions with a steep inclination (sites 21, 22, 24, 25, 26 and 29) and another of scattered directions with a lower inclination (sites 5, 23, 28, 30, 31 and 32). The inverted direction to the mean normal polarity direction is centered in the group of lower inclination reverse directions, suggesting that the high inclination directions may represent a period of pronounced secular variation or transitional field directions. 


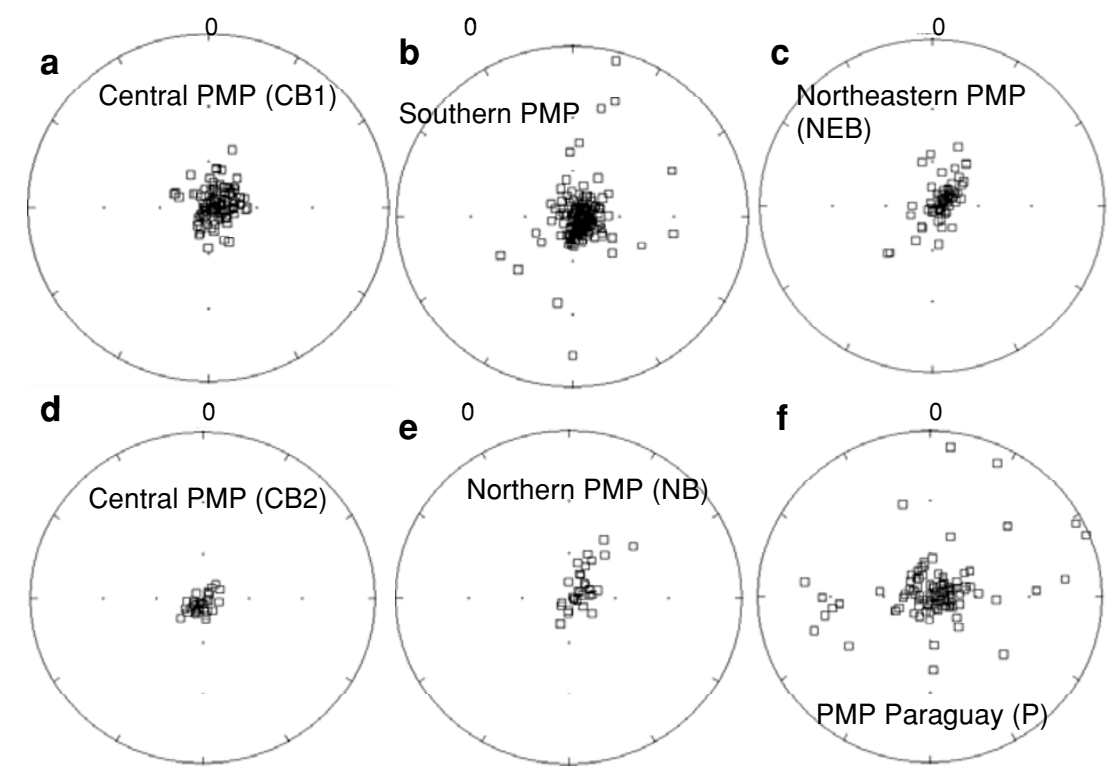

Fig. 13. South VGPs distribution from (a) Central PMP, Brazil (Ernesto et al., 1990), (b) Southern PMP, Brazil (Ernesto et al., 1990), (c) Northeastern PMP, Brazil (Ernesto et al., 1999), (d) Central PMP, Brazil (Alva-Valdivia et al., 2003), (e) Northern PMP, Brazil (Ernesto et al., 1990), (f) PMP, Paraguay (Ernesto et al., 1996).

Table 5. Best-fit great circle pole and associated elongations calculated for VGP distributions obtained from published data.

\begin{tabular}{lccccl}
\hline \multirow{2}{*}{ Locality } & \multicolumn{2}{c}{ Great circle pole } & Elongation & $N^{\mathrm{a}}$ & References \\
& Long & Lat. & & & \\
\hline Northern PMP, Brazil & 299.7 & -4.5 & 0.913 & 31 & Ernesto et al. (1990) \\
North-eastern PMP, Brazil & 299.9 & -3.9 & 0.890 & 66 & Ernesto et al. (1999) \\
Southern PMP, Brazil & 285.9 & -6.0 & 0.788 & 181 & Ernesto et al. (1990) \\
Central PMP, Brazil & 291.6 & -4.1 & 0.573 & 119 & Ernesto et al. (1990) \\
Central PMP, Brazil & 138.5 & -2.2 & 0.821 & 36 & Alva-Valdivia et al. (2003) \\
Misiones & 305.4 & -1.6 & 0.900 & 31 & This study \\
Paraguay & 162.8 & -3.3 & 0.766 & 72 & Ernesto et al. (1996) \\
\hline
\end{tabular}

${ }^{\mathrm{a}} N$, Number of VGPs

\section{VGP Distribution}

Despite the non-ideal number of samples included in this contribution, a conspicuous pattern is observed. The distribution of calculated VGPs is elongated (Fig. 12(a)). This elongation is more notable when only VGPs corresponding to normal polarities are considered (Fig. 12(b)). The reverse polarity VGPs are more scattered, and their distribution seems to be more circular (Fig. 12(c)). A possible cause of this behavior could be unremoved overprint in reverse samples that lead to more scattered characteristic directions.

If we consider all normal VGPs and only reverse VGPs corresponding to the group of antipodal directions to the normal ones, the distribution is elongated in a direction given by a great circle with a pole of $305.4^{\circ} \mathrm{E},-1.6^{\circ} \mathrm{S}$ (Fig. 12(d)).

Similarly, the distributions of VGPs of PMP in Brazil are elongated. In Fig. 13(a)-(e) the VGPs corresponding to the north (Ernesto et al., 1990), northeast (Ernesto et al., 1999), central (Ernesto et al., 1990; Alva-Valdivia et al., 2003) and south areas of the PMP (Ernesto et al., 1990) are plotted in the Southern Hemisphere. The distribution of VGPs obtained from basalts and alkaline rocks of Paraguay (Ernesto et al., 1996), although very scattered, also show a distinct elongation (Fig. 13(f)).

To compare VGP distributions from the different regions, we calculated best-fit great circles. The degree of ellipticity of each group was determined by the procedure of Oviedo and Vilas (1986): first, the VGP center of mass was calculated. Then, the VGPs were rotated in order to coincide the center of gravity with the $\mathrm{Z}$ axis. These vectors were projected onto a Lambert projection to avoid any change in the density of the distribution due to the projection. For the group of projected vectors, the eigenvalues $\lambda_{1}$ and $\lambda_{2}$ $\left(\lambda_{1} \geq \lambda_{2}\right)$, were calculated. The elongation of the group was determined by $\mathbf{e}=1-\left(\lambda_{1} / \lambda_{2}\right)^{1 / 2}$. A value for $\mathbf{e}$ near 0 indicates a circular distribution; if $\mathbf{e}=1$ the distribution is linear. The great circles and their associated elongations are given in Table 5.

These data indicate that VGPs from the three regions of Brazil and from Misiones are distributed along very similar great circles and that they have high elongation values (Fig. 14). The VGPs of the central area obtained by AlvaValdivia et al. (2003) have the lowest elongation values but nonetheless yield similarly oriented great circles. These authors used a graphic test and concluded that at $95 \%$ confidence levels a Fisher distribution hypothesis cannot be rejected. The scatter determined for these VGPs is slightly 


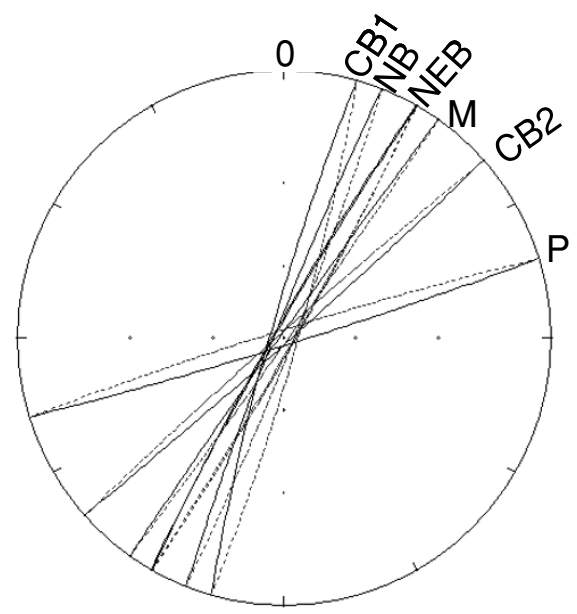

Fig. 14. Best-fit great circles for the VGPs distribution from: Central PMP, Brazil (CB1; Ernesto et al., 1990), Northern PMP, Brazil (NB; Ernesto et al., 1990), Northeastern PMP, Brazil (NEB; Ernesto et al., 1999), Misiones (M; this study), Central PMP, Brazil (CB2; Alva-Valdivia et al., 2003), PMP, Paraguay (P; Ernesto et al., 1996).

smaller than those calculated using data from other studies on these basalts and may be due to sampling bias or a sampled interval that is too short to average the paleosecular variation (Alva-Valdivia et al., 2003). The Paraguay VGPs have relatively high elongation values, but their corresponding great circle is far from the others. The large scatter of these data was attributed to possible structural problems or anomalous data from rolled blocks (Ernesto et al., 1996).

The scatter of mean directions observed in the first paleomagnetic study of Serra Geral basalts from Brazil (Creer, 1962) was attributed mainly to secular variation of the geomagnetic field. Similar scatter was found in subsequent, more systematic studies made on those rocks (Ernesto and Pacca, 1988). One of the causes of this dispersion could be that multiple flows with slow cooling registered geomagnetic field variations (Ernesto and Pacca, 1988). Also, it has been suggested that the low angular dispersion found from the PMP (less than the expected dispersion due to secular variation) can be an artifact of the inhomogeneous temporal distribution of data (Ernesto et al., 1990).

On the other hand it has also been suggested that an elongated distribution of South America Cretaceous paleomagnetic poles could be due to a complex trajectory of the plate (Valencio et al., 1983). An elongate distribution was also found in VGPs calculated from volcanic rocks of the Early Cretaceous rift of Sierra Chica, Córdoba, Argentina. This distribution was attributed to an inadequate structural correction or to an incomplete average of the paleosecular variation (Geuna and Vizán, 1998).

The VGPs from different sites of the PMP show similar elongations and are distributed along great circles. If the elongate distribution was due to fast plate movements, the VGP position along a great circle should be sequential, but this does not seem to be the case. On the other hand, local tectonic causes are also rejected. No tectonic tilting was observed in the study area. The attitude of the basalt flows is sub-horizontal. Dips, smaller than $5^{\circ}$, are probably more associated with paleotopography than with any tectonic tilt- ing. As a consequence, the elongated distribution of the VGPs cannot be attributed to tectonic causes.

A large number of ${ }^{40} \mathrm{Ar} /{ }^{39} \mathrm{Ar}$ aging analyses on the volcanic rocks of the Paraná basin (Renne et al., 1992a, 1992b, 1996a, 1997; Turner et al., 1994; Ernesto et al., 1999) show that only a few million years, (3-10) were required for the bulk of the PMP eruptions. Several polarity intervals are registered in the lava sequences, which allow one to assume that the involved time is of the order of several cycles of secular variation. The elongated distribution of VGPs could therefore be due to anomalous characteristics of paleosecular variation at this time of highly frequent polarity changes.

\section{Conclusions}

- The studied lavas belong to the central section of the Paraná Magmatic Province, and can be classified as tholeiitic basalts and andesi-basalts. They are of low$\mathrm{Ti}$ and intermediate-Ti, corresponding to Ribeira- and Paranapanema-types, two of the three youngest units of the sequence.

-Paleomagnetic and rock-magnetic studies suggest that the main magnetic mineral is poor-Ti titanomagnetite of SP to SD sizes and very low amounts of MD particles.

- The studied rocks typically yielded ChRMs with MAD $<5^{\circ}$; in all cases, with a MAD $<10^{\circ}$.

-The studied sequence has registered at least three polarity chrons, starting from a normal polarity at the base.

-The calculated VGPs present an elongate distribution similar to other distributions from VGPs published for Paraná Magmatic Province.

- This elongated distribution is unlikely to have been produced by any tectonic cause, either continental drift or local basculations.

- Since at least three polarity intervals are registered in the lava sequences, the involved time is of the order of several cycles of secular variation. The elongated distribution of VGPs could therefore be due to anomalous characteristics of paleosecular variation at this time of highly frequent polarity changes.

Acknowledgments. The authors acknowledge the financial support of CONICET (Argentina) and the University of Buenos Aires. We thank Alberto Ardolino and José Mendía, who participated in the early field work and kindly provided a collection of samples of the profile, Dr. Marco Iacumin, for collaborating in the petrographic field work and for performing chemical analyses at the University of Trieste. We would also like to thank an anonymous reviewer for his critical review. Special thanks are given to J. Glen for his numerous helpful comments. The paleomagnetic measurements were carried out at the INGEODAV.

\section{References}

Alva-Valdivia, L. M., A. Goguitchaichvili, J. Urrutia-Fucugauchi, J. Riisager, P. Riisager, and O. Ferreira-Lopes, Paleomagnetic poles and paleosecular variation of basalts from Paraná Magmatic Province, Brazil: geomagnetic and geodynamic implications, Phys. Earth Planet. Int., 138, 183-196, 2003.

Amaral, G., U. G. Cordani, K. Kawashita, and J. H. Reynolds, Potassiumargon dates of basaltic rocks from Southern Brazil, Geochem. Cosm. Acta, 30, 159-189, 1966.

Bellieni, G., E. M. Piccirillo, and B. Zanettin, Classification and nomenclature of basalts, IUGS, Subcommission of the Systematics of Igneous Rocks, Circ. 34, Contrib. Mineral. Petrol., 87, 1-191, 1981.

Bellieni, G., P. Brotzu, P. Comin-Chiaramonti, M. Ernesto, A. J. Melfi, I. 
G. Pacca, E. M. Piccirillo, and D. Stolfa, Flood basalt to rhyolite suites in the southern Paraná plateau (Brazil): paleomagnetism, petrogenesis and geodynamic implications, J. Petrol., 25, 579-618, 1984a.

Bellieni, G., P. Comin-Chiaramonti, L. S. Marques, A. J. Melfi, E. M. Piccirillo, A. J. Nardy, and A. Roisemberg, High- and low-TiO 2 flood basalts from the Paraná plateau (Brazil): Petrology and geochemical aspects bearing on their mantle origin, Neues Jbuch. Mineral., 150, 273306, 1984b.

Cordani, U. G., P. L. Sartori, and K. Kawashita, Geoquímica dos isótopos de estrôncio e a evolução da atividade vulcânica na Bacia do Paraná (SUl do Brasil) durante o Cretáceo, Ann. Acad. Bras. Ciênc., 58, 811$818,1980$.

Creer, K. M., Palaeomagnetism of the Serra Geral Formation, Geophys. J. Roy. Astr. S., 7, 1-22, 1962.

Creer, K. M., J. A. Miller, and A. G. Smith, Radiometric age of Serra Geral Formation, Nature, 207, 282-283, 1965.

Dankers, P. H. M., Magnetic properties of dispersal natural iron-oxides of known grain size, PhD thesis, University of Utrecht, Utrecht, 1978.

De La Roche, H., P. Leterrier, P. Grandclude, and M. Marchal, A classification of volcanic and plutonic rocks using R1-R2 diagrams and major element analyses. Its relationships with current nomenclature, Chem. Geol., 29, 183-210, 1980.

Dunlop, D. J., Theory and application of the Day plot $\left(M_{r s} / M_{s}\right.$ vs $\left.H_{c r} / H_{c}\right)$. 2. Application to data for rocks sediments and soils, J. Geophys. Res., 107, 101029/2001, 2002.

Dunlop, D. J. and Ö. Özdemir, Rock Magnetism Fundamentals and Frontiers, Cambridge University Press, Cambridge, UK, 1997.

Ernesto, M. and I. G. Pacca, Paleomagnetism of the Paraná Basin Flood volcancs, Southern Brasil, in The Mesozoic Flood Volcanism of the Paraná Basin: Petrogenetic and Geophys. Aspects, edited by E. M. Piccirillo and A. J. Melfi, IAG-USP Press, pp. 229-255, Sao Paulo, 1988.

Ernesto, M., I. G. Pacca, F. Y. Hiodo, and A. Nardy, Paleomagnetism of the Mesozoic Serra Geral Formation, Southern Brazil, Phys. Earth Planet. Int., 64, 153-175, 1990.

Ernesto, M., P. Comin-Chiaramonti, C. B. Gomes, A. M. Castillo, and J. C. Velázquez, Palaeomagnetic data from the Central Alkaline Province, Eastern Paraguay, in Alkaline Magmatism in Central-Eastern Paraguay, edited by C. B. Gomes and P. Comin-Chiaramonti, EDUSP/FAPESP, pp. 85-102, Sao Paulo, 1996.

Ernesto, M., I. B. Raposo, L. Marques, P. Renne, L. Diogo, and M. Min, Paleomagnetism, geochemistry and ${ }^{40} \mathrm{Ar} /{ }^{39} \mathrm{Ar}$ dating of the Northeastern Paraná Magmatic Province, J. Geodyn., 28, 321-340, 1999.

Evans, M. E. and F. Heller, Environmental magnetism. Principles and applications of environmagnetism, Elsevier Science, Geophy. Serv., 86, 2003.

Gentili, C. and H. Rimoldi, Mesopotamia, Academia Nacional de Ciencias, Segundo Simposio de Geología Regional Argentina, 1: 185-223. Córdoba, 1980.

Geuna, S., and H. Vizán, New Early Cretaceous paleomagnetic pole from Cordoba province, Geophys. J. Int., 135, 1085-1100, 1998.

Herz, N., Timing of spreading in the South Atlantic: information from Brazilian alkalic rocks, Geol. Soc. Am. Bull., 88, 101-112, 1977.

Kirschvink, J. L., The least-square line and plane and analysis of palaeomagnetic data, Geophys. J. Roy. Astr. S., 62, 699-718, 1980.

Lagorio, S. and P. Leal, Niveles peperíticos intercalados en los derrames lávicos de Serra Geral, provincia de Misiones. Actas $16^{\circ}$ Congr. Geol. Arg., 1: 847-850, 2005.

Le Bas, M. J., R. W., Le Maitre, A. Streckeisen, and B. Zanettin, A chemical classification of volcanic rocks based on total alkali-silica diagram, J. Petrol., 27, 745-750, 1986.

Maher, B. A. and R. Thompson, Quaternary Climates, Environments and Magnetism, Cambridge University Press, Cambridge, 1999.

Mantovani, M. S., U. G. Cordani, and A. Roisenberg, Geoquímica isotópica em vulcânicas ácidas da Bacia do Paraná e implicações genéticas associadas, Rev. Bras. Geoc., 15, 61-65, 1985.
Marzoli, A., L. Melluso, V. Morra, P. R. Renne, I. Sgrosso, M. D’Antonio, L. Duarte Morais, E. A. A. Morais, and G. Ricci, Geochronology and petrology of Cretaceous basaltic magmatism in the Kwanza basin (western Angola), and relationships with the Paraná-Etendeka continental flood basalt province, J. Geodyn., 28, 341-356, 1999.

Oviedo, E. S. and J. F. Vilas, Caracterización de la forma de datos direccionales. 14 reunión Científ. Asos. Arg. Geof. Geodyn. Res. 4TC7, 98, 1986.

Parry, L. G., Magnetization of immobilized particle dispersions with two distinct particles sizes, Phys. Earth Planet. Interiors, 28, 230-241, 1982.

Peate, D. W., C. J. Hawkesworth, and M. M. S. Mantovani, Chemical stratigraphy of the Paraná lavas (South America): classification of magma types and their spatial distribution, Bull. Volcanol., 55, 119-139, 1992.

Philips Procedure, X40 Software for XRF Analysis, Software Operation Manual, 1994.

Piccirillo, E. M. and A. J. Melfi, (Eds.), The Mesozoic Flood Volcanism from the Paraná Basin (Brazil): Petrogenetic and Geophysical Aspects, Universidad de São Paulo, San Pablo, 1988.

Piccirillo, E. M., M. I. Raposo, A. J. Melfi, P. Comin-Chiaramonti, G. Bellieni, U. G. Cordani, and K. Kawashita, Bimodal fissural volcanic suites from the Paraná Basin (Brazil): K-Ar age, Sr-isotopes and geochemistry, Geochim. Bras., 1, 53-69, 1987.

Renne, P. R., M. Ernesto, I. G. Pacca, R. S. R. S., J. Glen, M. Prévot, and M. Perrin, Rapid eruption of the Paraná flood volcanics, rifting of southern Gondwanaland and the Jurassic-Cretaceous boundary, Science, 258, 975-979, 1992a.

Renne, P. R., M. Ernesto, I. G. Pacca, A. J. R. Nardy, R. S. Coe, J. Glen, M. Prévot, and M. Perrin, Age and duration of Paraná flood volcanism in Brazil, EOS Trans. Am. Geophys. Union, 531, 1992 b.

Renne, P. R., K. Deckart, M. Ernesto, G. Féraud, and E. M. Piccirillo, Age of the Ponta Grossa dike swarm (Brazil), and implications to Paraná flood volcanism, Earth Planet. Sci. Lett., 144, 199-211, 1996a.

Renne, P. R., J. M. Glen, S. C. Milner, and A. R. Duncan, Age of Etendeka flood volcanism and associated intrusions in southwestern Africa, $\mathrm{Ge}$ ology, 24, 659-662, 1996b.

Renne, P. R., M. Ernesto, and S. C. Milner, Geochronology of the ParanáEtendeka Magmatic Province, EOS Trans. Am. Geophys. Union, F742, 1997.

Roberts, A. P., Y. Cui, Y. Yunlong, and K. L. Verosub, Wasp-waisted hysteresis loops.: Mineral magnetic characteristics and discrimination of components in mixed magnetic systems, J. Geophys. Res., 100, 1790917924, 1995.

Rocha-Campos, A. C., U. G. Cordani, K. Kawashita, H. M. Sonoki, and I. K. Sonoki, Age of the Paraná flood volcanism, in The Mesozoic Flood Volcanism of the Paraná Basin: Petrogenetic and Geophysics Aspects, edited by E. M. Piccirillo and A. J. Melfi, IAG-USP Press, pp. 25-46, 1988.

Sun, S-S. and W. F. McDonough, Chemical and isotopic systematics of oceanic basalts: implications for mantle composition and processes, in Magmatism in the Ocean Basins, edited by A. D. Saunders and M. J. Norry, vol. 42. Geol. Soc. London Spec. Publ., pp. 313-345, 1989.

Turner, S., M. Regelous, S. Kelley, C. J. Hawkesworth, and M. M. S. Mantovani, Magmatism and continental break-up in the South Atlantic: high precision ${ }^{40} \mathrm{Ar}-{ }^{39} \mathrm{Ar}$ geochronology, Earth Planet. Sci. Lett., 121, 333-348, 1994.

Valencio, D. A and J. F. Vilas, Paleomagnetism of some Middle Jurassic lavas from south-east Argentina, Nature, 225, 262-264, 1970.

Valencio, D., J. F. Vilas, and I. G. Pacca, The significance of the paleomagnetism of Jurassic-Cretaceous rocks from South America: predrift movements, hairpins and magnetostratigraphy, Geophys. J. Roy. Astr. S., 73, 135-151, 1983.

M. Mena (e-mail: mena@gl.fcen.uba.ar), M. J. Orgeira, and S. Lagorio 